\title{
Sequoia Couttsiae, Heer, at Hordle, Hants : A Study of the Characters which serve to distinguish Sequoia from Athrotaxis.
}

\author{
BY \\ M. E. J. CHANDLER, \\ Late Harkness Scholar, Neinnam College, Cambridge.
}

With five Figures in the Text.

$\mathrm{T} \mathrm{N}$ a note published recently ${ }^{1} \mathrm{I}$ drew attention to the fact that the Conifer remains of the Lower Headon Beds of Hordle (Hordwell), Hants, which Mr. Starkie Gardner had referred to Athrotaxis, ${ }^{2}$ must now be placed in the genus Sequoia.

This conclusion was based on the study of leaves, cones, and seeds, the relationship of these organs being proved by the discovery of one cone attached to its twig, and of another still bearing seeds. The material examined was collected from the Hordle 'Leaf-Bed', ${ }^{3}$ where it is very abundant.

A comparison of the Hordle and Bovey Tracey specimens has shown that, though in error as to the generic name, Mr. Starkie Gardner was right in classing the Bovey and Hordle fossils as the same species, for the two plants are identical in character. Hence the excellent specific description of Heer ${ }^{4}$ renders superfluous further reference to the macroscopic characters, except in regard to certain points not mentioned by him. These will be dealt with as occasion requires in treating of the different plant organs.

To the earlier descriptions of the twigs there is nothing new to add, their condition being such as to render section-cutting unprofitable labour.

Microscopic study of the leaves shows that stomata cccur on both

1 Ann. Bot., vol. xxxv, No. cxxxix, July $192 \mathrm{I}$.

2 Starkie Gardner : Monograph of Palaeontographical Soc. The Eocene Flora, vol. ii, I883-6, p. 9o, P1. X, Figs. 6-9.

3 Bed Io of Tawney and Keeping: Quart. Journ. Geol. Soc., vol. xxxiv (1883), p. 566 . On the Section at Hordwell Cliffs.

${ }^{4}$ Heer: Phil. Trans. Roy. Soc., Part III, I862. On the Lignite Formation of Bovey Tracey, Devonshire, p. 33, Plates VIII, IX, X.

[Annals of Botany, Vol. XXXVI. No. CXLIII. July, 1922.] 
surfaces; on the lower they are irregularly scattered from apex to base, but are few in number, or absent, around the margin and along the median dorsal angle. On the upper they are very abundant, occurring more or less unevenly on either side of the median line, both on the decurrent and falcate parts of the leaf, but they are absent from the median line itself and from the thick margin (Fig. I, b). Nevertheless, despite the general differentiation into stomata-bearing and non-stomata-bearing regions, the limiting line between the two is ill-defined and sinuous. Though the general distribution of the stomata can readily be seen, the actual details of cell structure can only be distinguished occasionally. Each stoma is ringed by about four narrow, parallel-sided cells (Fig. 2, b), and usually three or more stomata occur in a row placed end to end, while the

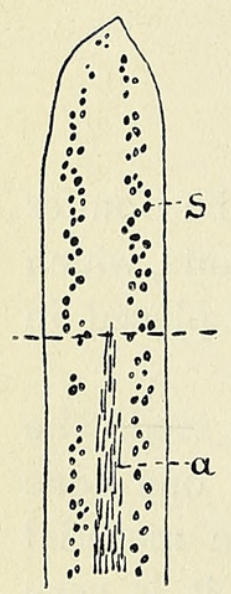

(a)

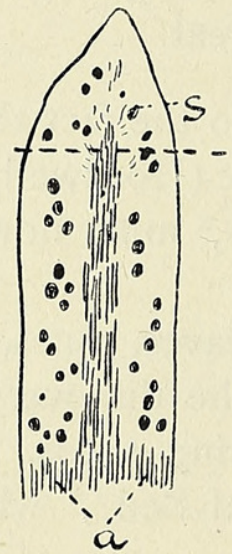

(b)

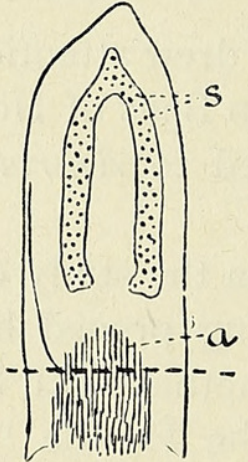

(c)

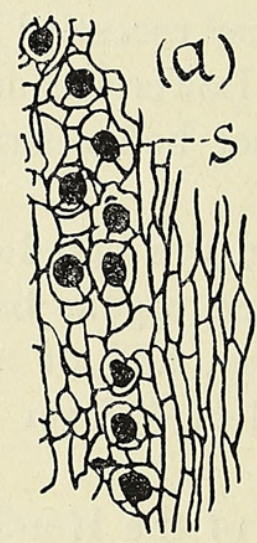

FIG. 2. Detail of stomata and nonstomata-bearing cuticle. (a), S. gigantea; (b), S. Couttsiae; (c), A. laxifolia; $s=$ stomata.

of leaves. (a), Sequoia gigantea; (b), S. Couttsiae; (c), Athrotaxis laxifolia; $s=$ stomata. Above dotted line = falcate part of leaf. Below dotted line = decurrent part of leaf. $a=$ attached area.

cells of the interspaces have curved outlines. In areas where stomata are absent the cuticle cells are elongate parallel to the length of the leaf.

A comparison of the fossil with recent Sequoia and Athrotaxis shows that it is related to the former (compare Fig. I, $a, b, c$, and Fig. 2, $a, b, c$ ), for in Athrotaxis the stomata on the lower surface of the leaf occur only where the decurrent base merges into the falcate portion (compare description of Sequoia above), while on the upper surface they are confined to the falcate region, where they occupy a clear-cut, inverted-V-shaped tract shown in Fig. I, $c$. There is no alined arrangement; instead, stomata are evenly and thickly scattered over the whole V-shaped area; the cells between them are triangular and are radially arranged (Fig. 2, c). The evidence from the leaves is, then, fairly conclusive that the fossil belongs not to Athrotaxis but to Sequoia. 
In Heer's account of the cones of S. Couttsiae ${ }^{1}$ the following features, which have a generic significance, have been overlooked. The seminiferous scale and bract are almost completely fused to form a single structurethe cone-scale. In each cone-scale there are two regions, the stalk and the escutcheon; in the latter only do traces of the original double structure of the scale remain, but there a small mucro and associated transverse ridge seem to represent the apex of the bract and the line of fusion respectively. This is a character of recent Sequoias, though in these the complete ridge is only seen in the basal scales of S. sempervirens; in all other scales of both species the mucro is sunk in a groove and the ridge is apparent only at the edge.

The surface of the escutcheon is always ornamented with radial wrinkles. Its form may be quadrilateral, pentagonal, hexagonal, or irregular, and its margin is always clearly defined (Figs. $3, a, b$, and $4, a, c$ ); it is set at a marked angle to the stalk, there is never a gradual passage from one to the other. The stalk occasionally meets the escutcheon symmetrically at its centre and at a right angle ; more frequently, it meets it asymmetrically, towards its low $\in \mathrm{r}$ margin and at an obtuse angle; this angle is greatest in the lowest scales, where it may be about $150^{\circ}$. Thus there are two extreme forms of scale-peltate and imbricate-with a variety of intermediate forms.

In the recent $S$. sempervirens both these types are present; the imbricate character is, however, confined to a few basal scales (Fig. 3, c). In $S$. gigantea it is completely lost, and only peltate scales remain. A pparently it was the presence in the fossil of imbricate scales which led Mr. S. Gardner to identify it as Athrotaxis, for he wrote that an uncrushed specimen ' revealed the fact that the scales of the cone are overlapping or imbricate as in Athrotaxis, and not at right angles to the axis as in Sequoia'. ${ }^{2}$ As the new evidence from $S$. sempervirens shows that imbricate scales can occur, their presence in the fossil is not sufficient cause for placing it in Athrotaxis rather than in Sequoia when all other evidence points to the latter genus, as will be shown.

The cone-scales of Athrotaxis differ radically from those of the fossils and of the recent Sequoia. In Athrotaxis bract and seminiferous scale retain their identity to a marked degree. The thin, horny bract projects as a pointed tongue beyond the woody, seminiferous scale; hence the lower side of the cone-scale shows a continuous surface of bract from attachment to apex. There is no differentiation into stalk and escutcheon, and no ornamentation of the exposed surface. The seminiferous scale has a thickened, involute margin (Figs. $3, d$, and $4, b, d$ ).

Further, while Sequoia and the fossil agree, Sequoia and Athrotaxis differ widely in respect of the number and mode of attachment of the seeds

$$
1 \text { Loc. cit. }
$$


on each scale. In the fossil and in Sequoia the attachment is at a third of the length of the scale from its distal margin, in Athrotaxis the attachment scars are found immediately adjacent to the involute margin (Fig. 4, b) ; and again, in the fossil five and six seeds have been counted on a scale, while recent Sequoia scales each bear from five to nine; but in Athrotaxis the maximum is five, and the limits of variation are from three to five.

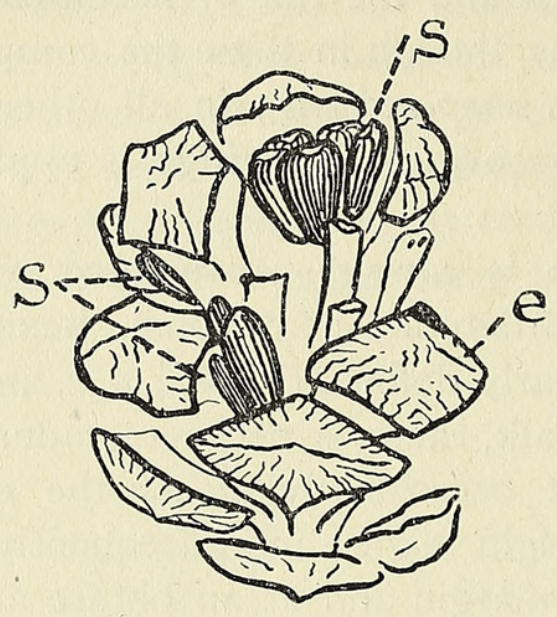

(a)

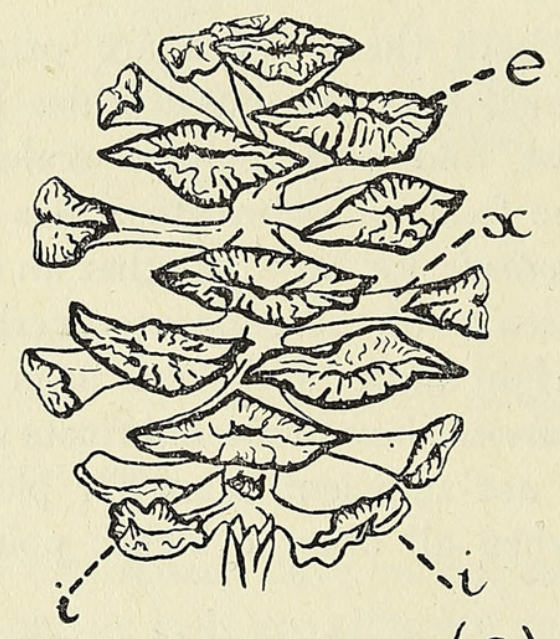

(c)

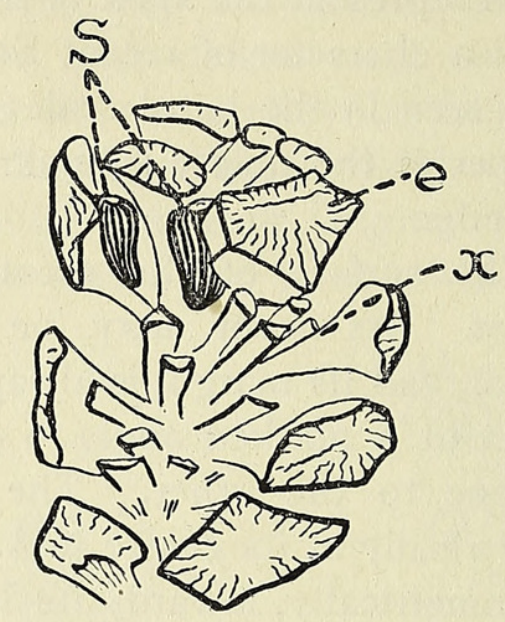

(b)

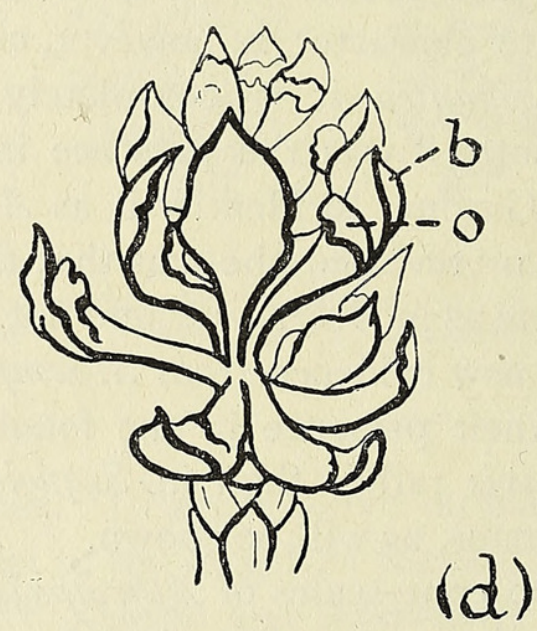

FIG. 3. Cones. (a) and (b), two aspects of a cone of $S_{0}$ Couttsiae; (c), S. sempervirens; $(d)$, Athrotaxis laxifolia. $s$, seeds; $i$, imbricate scales; 0 , seminiferous scale; $b$, bract; $e$, escutcheon; $x$, stalk. All magnified.

Once again, therefore, there is adequate reason for referring the fossil to Sequoia.

To the previous descriptions of the seeds of S. Couttsiae I would add that considerable variations of size and shape occur; the smallest specimens measured were $2.5 \mathrm{~mm}$. long and $2 \mathrm{~mm}$. broad, the largest $5 \mathrm{~mm}$. long and $2.5 \mathrm{~mm}$. broad. The shape varies from a broad oval to a very narrow one; sometimes the apex is provided with a mucro, and though a curved embryo 
is common, straight ones are found too, both in the Bovey and in the Hordle material. The embryo in the fossil is long and narrow, and the wing is thick and horny in texture. The testa is covered with close longitudinal striae whose direction of curvature conforms over the embryo

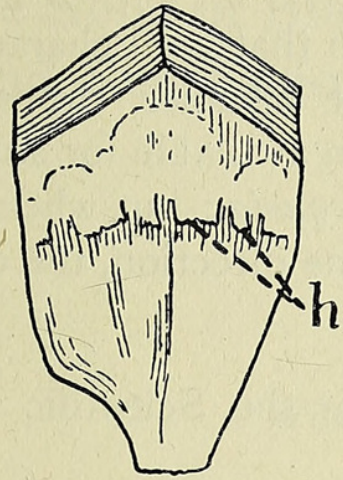

(a)

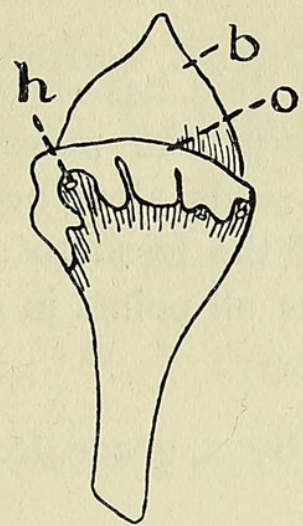

(b)

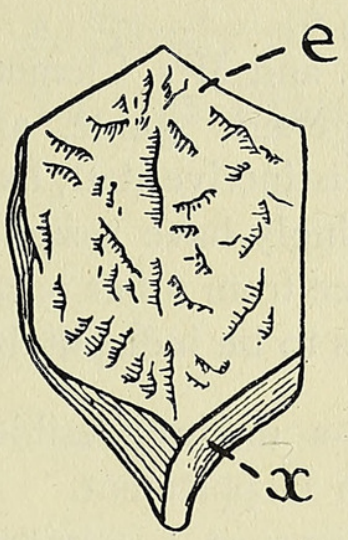

(c)

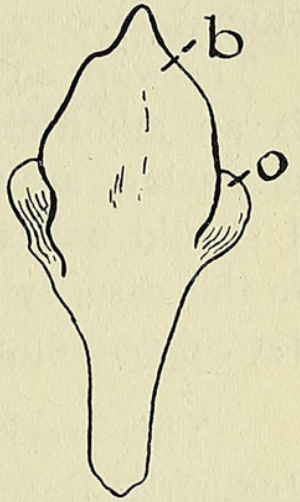

(d)

Fig. 4. Cone-scales. (a), S. Couttsiae, upper surface. (c), Do., lower surface. (b), Athrotaxis laxifolia, upper surface. (d), Do., lower surface. $e$, escutcheon; $x$, stalk; $b$, bract; 0 , seminiferous scale; $h$, attachment of seed. All magnified.
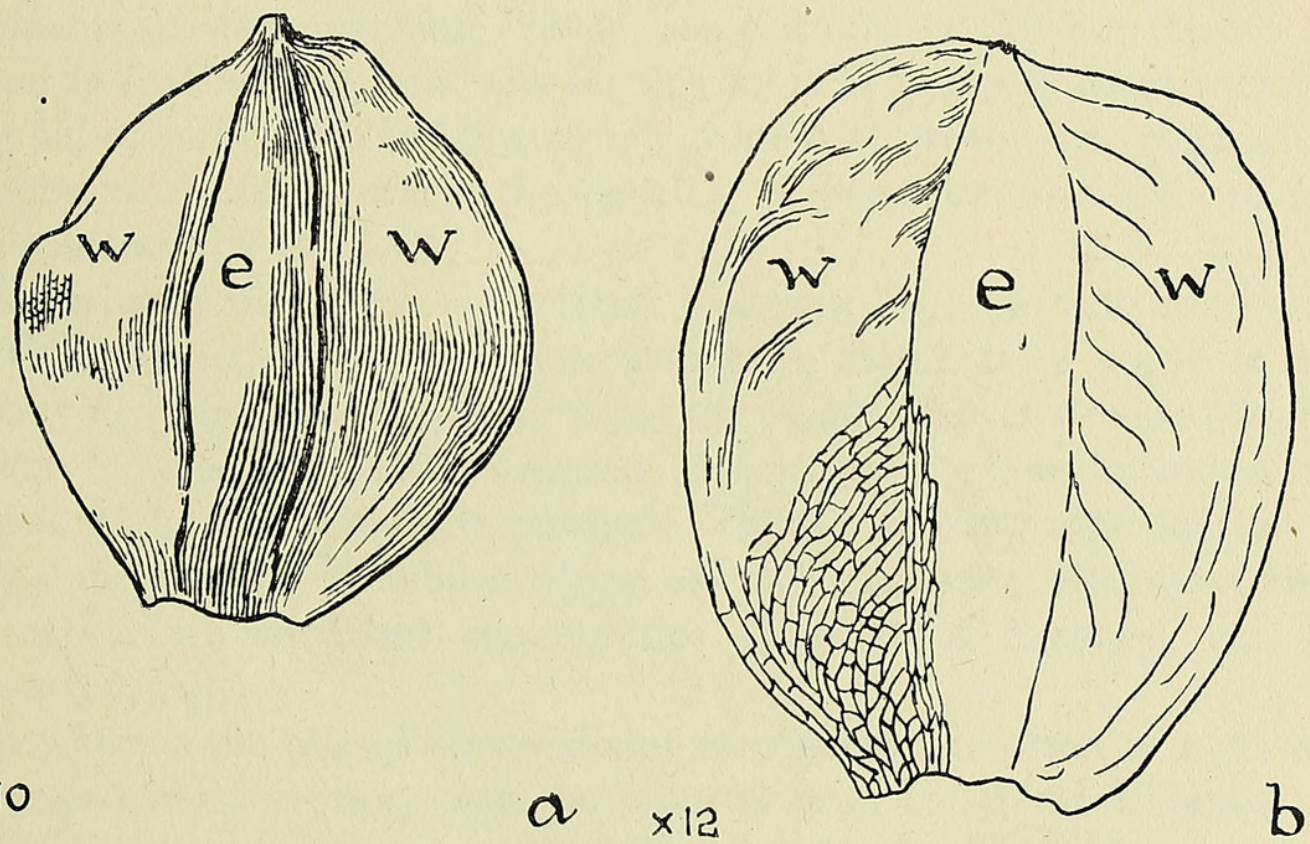

$\times 10$

a $\times 12$

b

Fig. 5. Seeds. (a), S. Couttsiae; (b), Athrotaxis selaginoides. e, embryo; w, wing.

to the curvature of the embryo, over the wing to the curvature of the wing (Fig. 5, a). In the hollows between the striae pits occur in longitudinal rows; they are most conspicuous in worn specimens. The likeness which the fossils bear to recent Sequoia seeds, more especially to S. sempervirens, is very striking.

In Athrotaxis the seeds, instead of being horny and tough all over 
have a membranous, puckered wing, whose surface is formed of large, inflated, oblong or polygonal cells. Only near the margin are their longer axes parallel to the lateral edge of the wing, elsewhere they are inclined obliquely to it; thus they are arranged in lines which sweep transversely across the wing, meeting the edge of the embryo at an angle of about $50^{\circ}$ (Fig. 5, b).

The work of Mr. and Mrs. Clement Reid has shown that seed character is an admirable generic guide, and in the present instance the seed characters are so distinctive that, had seeds alone been available for study, I should unhesitatingly have assigned the fossil to Sequoia; but when, as in this case, evidence from other organs all points in one direction, the case for Sequoia appears to be indisputable.

This work was made possible by a grant from the Scientific and Industrial Research Department.

With great pleasure I acknowledge my debt to Mrs. Reid, whose experience and collection of seeds have been freely placed at my disposal, and who has also given valuable help and criticism.

I would also thank the Director of the Royal Gardens, Kew, for kindly lending herbarium sheets of Athrotaxis. 


\section{$2 \mathrm{BHL}$ Biodiversity Heritage Library}

Chandler, Marjorie Elizabeth Jane. 1922. "Sequoia couttsiae, Heer, at Hordle, Hants: a study of the characters which serve to distinguish Sequoia from Athrotaxis." Annals of botany 36, 385-390.

https://doi.org/10.1093/oxfordjournals.aob.a089813.

View This Item Online: https://www.biodiversitylibrary.org/item/234428

DOI: https://doi.org/10.1093/oxfordjournals.aob.a089813

Permalink: https://www.biodiversitylibrary.org/partpdf/319050

\section{Holding Institution}

Smithsonian Libraries

\section{Sponsored by}

Biodiversity Heritage Library

\section{Copyright \& Reuse}

Copyright Status: Not in copyright. The BHL knows of no copyright restrictions on this item.

This document was created from content at the Biodiversity Heritage Library, the world's largest open access digital library for biodiversity literature and archives. Visit BHL at https://www.biodiversitylibrary.org. 